\title{
PENGEMBANGAN MODUL IPA BERBASIS KONTEKSTUAL MATERI KALOR DAN PERPINDAHANNYA UNTUK MENINGKATKAN KEMAMPUAN BERPIKIR KRITIS PESERTA DIDIK SMPKELAS VII
}

\author{
Siti Darmawati ${ }^{1}$, Ashadi $^{2}$, Sarwanto $^{3}$ \\ ${ }^{1}$ Program Studi Magister Pendidikan Sains FKIP Universitas Sebelas Maret \\ Surakarta, 57126, Indonesia \\ siti_darmawati12@yahoo.co.id \\ ${ }^{2}$ Program Studi Magister Pendidikan Sains FKIP Universitas Sebelas Maret \\ Surakarta, 57126, Indonesia \\ ashadi_uns@yahoo.com \\ ${ }^{3}$ Program Studi Magister Pendidikan Sains FKIP Universitas Sebelas Maret \\ Surakarta, 57126, Indonesia \\ sarwanto@fkip.uns.ac.id
}

\begin{abstract}
Abstrak
Kemampuan berpikir kritis peserta didik belum optimal dan media cetak yang digunakan dalam pembelajaran belum mampu meningkatkan kemampuan berpikir kritis peserta didik. Penelitian ini bertujuan untuk mengembangkan modul IPA dan mendeskripsikan karakteristik, kelayakan serta keefektifan modul IPA berbasis kontekstual materi kalor dan perpindahannya untuk meningkatkan kemampuan berpikir kritis peserta didik SMP kelas VII. Subjek dalam penelitian ini adalah peserta didik kelas VII SMP Negeri 1 Weru. Jenis penelitian ini adalah pengembangan, yang mengacu pada model pengembangan Borg dan Gall yaitu: 1) analisis kebutuhan; 2) perencanaan; 3) pengembangan produk; 4) uji coba tahap awal; 5) revisi produk; 6) uji coba lapangan utama; dan 7) revisi produk. Uji coba lapangan dilakukan menggunakan pre-experimental design jenis one-shot case study. Teknik analisis yang digunakan adalah deskriptif kualitatif-kuantitatif. Hasil penelitian menunjukkan bahwa: (1) modul IPA berbasis kontekstual memiliki karakteristik yaitu memuat langkah pembelajaran berbasis kontekstual yang diintegrasikan kemampuan berpikir kritis pada setiap tahapnya, masing-masing kegiatan belajar terdiri atas satu kompetensi dasar dan modul IPA berbasis kontekstual bersifat self instruction; (2) modul IPA berbasis kontekstual termasuk kategori layak karena telah melalui uji kelayakan dari ahli materi, ahli media dan ahli bahasa dengan nilai 3,74 kategori sangat baik, praktisi pendidikan dan teman sejawat dengan nilai 3,22 kategori baik, serta melalui tahap uji coba produk dan revisi; (3) modul IPA berbasis kontekstual efektif meningkatkan kemampuan berpikir kritis dan hasil belajar aspek pengetahuan, keterampilan dan sikap peserta didik. Berdasarkan hasil uji coba lapangan utama bahwa modul IPA berbasis kontekstual dapat digunakan sebagai bahan ajar IPA pada materi kalor dan perpindahannya di SMP kelas VII.
\end{abstract}

Kata Kunci: modul IPA, kontekstual, berpikir kritis, kalor, one-shot case study.

\section{Pendahuluan}

Abad ke-21 sebagai era globalisasi merupakan ajang persaingan bebas antar bangsa-bangsa di dunia, sehingga menuntut perkembangan yang cepat dan pola pikir setiap individu agar mampu bersaing baik di masa sekarang maupun di masa mendatang. Pola pikir individu dapat dikembangkan melalui pendidikan secara umum dan melalui proses pembelajaran IPA secara khusus. Keterampilan berpikir seperti kemampuan berpikir kritis peserta didik menjadi penting untuk dikembangkan 
sebab berpikir kritis merupakan proses dasar suatu keadaan dinamis yang memungkinkan peserta didik mampu menanggulangi ketidaktentuan di masa depan atau peserta didik dapat bersaing di era globalisasi agar dapat mempertahankan dirinya dalam memenangkan persaingan. Menurut Lambertus (2009: 140) bahwa berpikir kritis dapat membantu seseorang memahami bagaimana ia memandang dirinya sendiri, bagaimana ia memandang dunia, dan bagaimana ia berhubungan dengan orang lain, membantu meneliti perilaku diri sendiri, dan menilai diri sendiri. Thelma et al (2007) menyatakan bahwa berpikir kritis adalah komponen penting dari pendidikan sains, dan bahwa hal itu harus dikejar di tingkat menengah dan pasca-sekolah menengah.

Manfaat pelatihan kemampuan berpikir kritis peserta didik menurut Rosana (2014: 378) bahwa berpikir kritis sangat berguna bagi seorang mahasiswa terutama membantu dalam memperoleh pengetahuan, memperbaiki teori, memperkuat argumen, mengemukakan dan merumuskan pertanyaan dengan jelas, mengumpulkan, menilai dan menafsirkan informasi dengan efektif, membuat kesimpulan dan menemukan solusi masalah berdasarkan alasan yang kuat, membiasakan berpikiran terbuka dan mengomunikasikan gagasan, pendapat dan solusi dengan jelas kepada lainnya. Facione (2011: 4) mengatakan bahwa berpikir kritis adalah berpikir yang memiliki tujuan (membuktikan sebuah pendapat, menafsirkan arti dari sesuatu dan memecahkan masalah). Indikator berpikir kritis menurut Facione terdiri atas enam indikator meliputi interpretasi, analisis, inferensi, evaluasi, eksplanasi dan regulasi diri. Hasil observasi pelaksanaan pembelajaran IPA di kelas VII SMP Negeri 1 Weru bahwa, peserta didik kurang merespons pertanyaan guru dan peserta didik kurang bertanya. Ini mengindikasikan bahwa terdapat kesulitan belajar yang dialami oleh peserta didik pada materi pembelajaran yang menuntut pemahaman terhadap objek yang dipelajari dan sebagian besar peserta didik mengalami kesulitan untuk mengkonstruksi sendiri pengetahuannya. Penyebab terjadinya kesenjangan-kesenjangan tersebut adalah kemampuan berpikir kritis peserta didik yang kurang optimal. Hasil analisis awal profil kemampuan berpikir kritis peserta didik SMP Negeri 1 Weru, bahwa kemampuan berpikir kritis peserta didik masih kurang optimal. Hasil analisis ratarata persentase kemampuan berpikir kritis peserta didik untuk kemampuan interpretasi sebesar $73,33 \%$ dengan kriteria cukup, kemampuan analisis $57,50 \%$ dengan kriteria kurang, kemampuan inferensi $62,50 \%$ dengan kriteria kurang, kemampuan evaluasi 46,66\% dengan kriteria kurang, kemampuan eksplanasi $50,00 \%$ dengan kriteria kurang dan kemampuan regulasi diri $69,16 \%$ dengan kriteria kurang.

Peserta didik dapat dilatih untuk berpikir kritis, sebagaimana menurut Lambertus (2009: 140) bahwa Setiap orang dapat belajar untuk berpikir kritis karena otak manusia secara konstan berusaha memahami pengalaman. Pencariannya yang terus menerus akan makna, otak dengan tangkas menghubungkan ide abstrak dengan konteksnya di dunia nyata. Rosana (2014: 378) berpendapat bahwa keterampilan berpikir merupakan proses keterampilan yang bisa dilatihkan, artinya dengan menciptakan suasana pembelajaran yang kondusif akan merangsang siswa untuk meningkatkan kemampuan berpikir. Suasana pembelajaran yang kondusif terjadi apabila terdapat sistem interaksi edukasi dalam pembelajaran. Sistem interaksi edukasi tersebut sebagaimana menurut Prastowo (2014: 26) terdiri atas tujuh komponen yaitu tujuan pembelajaran, bahan ajar yang menjadi isi interaksi, siswa yang aktif mengalami, guru sebagai pelaksana, metode pembelajaran, lingkungan belajar dan evaluasi pembelajaran. Bahan ajar dapat berupa buku paket, handout, modul dan LKS. Modul pembelajaran merupakan suatu program belajar mengajar yang terkecil, 
yang dipelajari oleh siswa sendiri secara perseorangan atau diajarkan oleh siswa kepada dirinya sendiri (self-instructional) (Winkel, 2009: 472).

Komponen interaksi edukasi selanjutnya dalam proses belajar mengajar IPA adalah metode pembelajaran yang dapat mengembangkan kemampuan berpikir kritis peserta didik. Menurut Hosnan (2014: 268) bahwa pendekatan kontekstual memberikan penekanan pada penggunaan berpikir tingkat tinggi, transfer pengetahuan, pemodelan, informasi dan data dari berbagai sumber. Berns dan Erickson (2001: 3) berpendapat bahwa tujuan pembelajaran kontekstual dapat didasarkan pada penggunaan kemampuan berpikir tingkat tinggi seperti pemecahan masalah, berpikir kritis, dan pengambilan keputusan. Selanjutnya Berns dan Erickson (2001) mendefinisikan bahwa: Pembelajaran kontekstual merupakan sebuah konsep belajar mengajar yang membantu guru menghubungkan isi mata pelajaran dengan situasi dunia nyata dan memotivasi siswa membuat hubungan antara pengetahuan dan aplikasinya untuk kehidupan siswa sebagai anggota keluarga, warga negara, dan pekerja, serta terlibat dalam pembelajaran yang membutuhkan kerja keras. Pembelajaran kontekstual terdiri atas tujuh komponen yaitu, konstruktivisme (constructivism), bertanya (questioning), menemukan (inquiry), masyarakat belajar (learning community), pemodelan (modelling), refleksi (reflection) dan penilaian nyata (authentic assessment).

Hasil analisis terhadap buku sekolah elektronik (BSE) kurikulum 2013 SMP Negeri 1 Weru, bahwa bahan ajar yang digunakan telah mengukur kemampuan berpikir kritis peserta didik yaitu kemampuan interpretasi, kemampuan menganalisis (seperti kemampuan merumuskan masalah, mengajukan dugaan sementara dan menyajikan data dalam bentuk tabel), inferensi, mengeksplanasi dan kemampuan mengevaluasi menggunakan pendekatan saintifik terutama untuk materi kalor dan perpindahannya, namun belum mengukur kemampuan regulasi diri dan kemampuan menganalisis seperti menyajikan data dalam bentuk grafik atau diagram. Berdasarkan analisis perangkat pembelajaran (RPP) SMP Negeri 1 Weru yang memuat materi kalor dan perpindahannya bahwa kemampuan berpikir kritis peserta didik yang diukur meliputi kemampuan interpretasi, eksplanasi, kemampuan analisis seperti menyajikan data praktukum dalam bentuk tabel dan kemampuan menyimpulkan, namun belum mengukur kemampuan evaluasi, kemampuan regulasi diri dan kemampuan analisis seperti merumuskan masalah, mengajukan dugaan sementara dan menyajikan data dalam bentuk grafik.

Hasil analisis kebutuhan guru dan peserta didik pada kelas VII SMP Negeri 1 Weru bahwa: (1) guru dan peserta didik membutuhkan modul IPA berbasis kontekstual yang dapat melatih kemampuan berpikir kritis peserta didik; (2) guru dan peserta didik membutuhkan modul IPA yang materinya dikaitkan dengan fenomena-fenomena alam (kejadiankejadian nyata) dalam kehidupan seharihari; dan (3) guru telah mengukur kemampuan berpikir kritis peserta didik namun tidak di setiap kegiatan belajar, sehingga guru menginginkan adanya kegiatan pembelajaran yang dapat mengukur kemampuan berpikir kritis peserta didik di setiap kegiatan belajar.

Hasil analisis ulangan harian peserta didik kelas VII A - VII E pada materi kalor dan perpindahannya secara berturut-turut memiliki rata-rata $57,40,66,17,61,40$, 52,03 dan 50,67. Hasil analisis persentase deskripsi nilai akhir IPA peserta didik SMP Negeri 1 Weru kelas VII A - VII E Semester II Tahun Ajaran 2014/2015 aspek pengetahuan pada materi kalor dan perpindahannya bahwa sebanyak $66,7 \%$ pengetahuan peserta didik kelas VII A tentang materi kalor dan perpindahannya tergolong masih kurang, kelas VII B sebanyak 43,3\%, kelas VII C sebanyak $53,3 \%$, kelas VII D sebanyak 63,3\% dan kelas VII E sebanyak 76,7\%. Hasil analisis 
data ujian nasional SMP Negeri 1 Weru Tahun Pelajaran 2014/2015 bahwa penguasaan materi IPA pada konsep zat dan kalor serta kegunaannya dalam kehidupan sehari-hari pada tingkat sekolah adalah $56,22 \%$, Kota/Kabupaten sebesar 64,05\%, Propinsi $62,05 \%$ dan di tingkat Nasional sebesar $66,4 \%$.

Berdasarkan masalah-masalah dalam pembelajaran IPA yang telah dikemukakan tersebut, maka perlu dikembangkan bahan ajar (modul) IPA berbasis kontekstual untuk meningkatkan kemampuan berpikir kritis peserta didik dengan materi kalor dan perpindahannya. Tujuan penelitian dan pengembangan modul IPA berbasis kontekstual adalah untuk: (1) mengetahui karakteristik modul IPA berbasis kontekstual materi kalor dan perpindahannya; (2) mengetahui kelayakan modul IPA berbasis kontekstual materi kalor dan perpindahannya untuk meningkatkan kemampuan berpikir kritis peserta didik kelas VII; dan (3) Mengetahui keefektifan modul IPA berbasis kontekstual materi kalor dan perpindahannya untuk meningkatkan kemampuan berpikir kritis peserta didik kelas VII.

\section{Metode Penelitian}

Penelitian ini merupakan jenis penelitian pengembangan (research and development), merupakan metode penelitian yang digunakan untuk menghasilkan produk tertentu dan menguji keefektifan produk tersebut (Sugiyono, 2011: 164). Penelitian dan pengembangan modul mengikuti langkah-langkah Borg dan Gall meliputi: 1) analisis kebutuhan; 2) perencanaan; 3) pengembangan produk; 4) uji coba tahap awal; 5) revisi produk; 6) uji coba lapangan utama; 7) revisi produk; 8) uji coba lapangan operasional; 9) revisi produk akhir; dan 10) diseminasi dan implementasi produk. Uji coba lapangan dilakukan menggunakan pre-experimental design jenis One-Shot Case Study. Teknik analisis data menggunakan deskriptif kualitatif-kuantitatif. Subjek dalam penelitian ini adalah peserta didik kelas VII SMP Negeri 1 Weru.

Validasi modul oleh ahli, praktisi pendidikan dan teman sejawat berupa lembar check list menggunakan skala likert dengan ketentuan skor $4=$ sangat baik, $3=$ baik, 2 = kurang dan $1=$ sangat kurang. Kemampuan berpikir kritis peserta didik diukur melalui keberhasilan siswa menjawab pertanyaan-pertanyaan berpikir kritis yang ada dalam modul. Penilaian hasil belajar peserta didik meliputi aspek pengetahuan melalui tes, keterampilan melalui observasi dan sikap melalui observasi serta penilaian diri menggunakan skala likert dengan rentang angka 4 (sangat baik) - 1 (kurang). Hasil belajar peserta didik aspek pengetahuan juga dianalisis berdasarkan KKM SMP Negeri 1 Weru yaitu 71 .

\section{Hasil Penelitian dan Pembahasan}

Pengembangan modul IPA berbasis kontekstual sesuai dengan tahap-tahap pengembangan modul Borg dan Gall. Tahap pertama adalah melakukan analisis kebutuhan. Hasil analisis kebutuhan guru dan peserta didik pada kelas VII SMP Negeri 1 Weru bahwa: (1) guru dan peserta didik membutuhkan modul IPA berbasis kontekstual yang dapat melatih kemampuan berpikir kritis peserta didik; (2) guru dan peserta didik membutuhkan modul IPA yang materinya dikaitkan dengan fenomena-fenomena alam (kejadiankejadian nyata) dalam kehidupan seharihari; dan (3) guru menginginkan adanya kegiatan pembelajaran yang dapat mengukur kemampuan berpikir kritis peserta didik di setiap kegiatan belajar. Perencanaan penyususnan modul IPA berbasis kontekstual menggunakan materi kalor dan perpindahannya dengan tujuan untuk mengukur kemampuan berpikir kritis peserta didik. Kompetensi dasar yang digunakan dalam modul adalah KD 3.7, KD 4.10 dan KD 4.

Tahap pengembangan produk meliputi desain awal modul, validasi desain 
dan revisi. Desain awal modul IPA berbasis kontekstual meliputi cover, halaman francis, kata pengantar, daftar isi, daftar tabel, daftar gambar, peta kedudukan modul, pendahuluan (meliputi, langkahlangkah pembelajaran kontekstual untuk mengukur kemampuan berpikir kritis, kompetensi inti dan kompetensi dasar, deskripsi, waktu, dan petunjuk penggunaan modul), glosarium, peta konsep, kegiatan belajar I, kegiatan belajar II, kegiatan belajar III dan daftar pustaka. Kegiatan belajar I membahas materi pada kompetansi dasar 3.7 yakni memahami konsep suhu, pemuaian, kalor, perpindahan kalor, dan penerapannya dalam mekanisme menjaga kestabilan suhu tubuh pada manusia dan hewan serta dalam kehidupan sehari-hari, kegiatan belajar II membahas materi pada kompetansi dasar 4.10 melakukan percobaan untuk menyelidiki suhu dan perubahannya, serta pengaruh kalor terhadap perubahan suhu dan perubahan wujud benda serta kegiatan belajar III I membahas materi pada kompetansi dasar 4.11 Melakukan penyelidikan terhadap karakteristik perambatan kalor secara konduksi, konveksi, dan radiasi.

Langkah pembelajaran pada modul memuat langkah pembelajaran berbasis kontekstual yang mengintegrasikan kemampuan berpikir kritis pada setiap tahapnya. Kegiatan pembelajaran diawali dengan Bertanya (questioning). Peserta didik mengamati fenomena yang disajikan dalam modul kemudian melakukan interpretasi (menjawab pertanyaan) yang berkaitan dengan fenomena yang disajikan. Jawaban peserta didik pada tahap questioning digunakan untuk mengukur kemampuan berpikir kritis peserta didik yaitu kemampuan interpretasi. Facione (2011) mendeskripsikan bahwa interpretasi merupakan kemampuan untuk memahami dan mengungkapkan makna atau arti dari berbagai pengalaman, situasi, data dan peristiwa. Bagian kedua adalah Penemuan (inquiry). Pada tahap ini peserta didik merumuskan masalah berdasarkan fenomena yang disajikan, mengajukan dugaan (jawaban) sementara, mengumpulkan data/melakukan percobaan, menganalisis dan menyajikan hasil dalam bentuk tabel dan grafik. Hasil pekerjaan peserta didik pada tahap penemuan digunakan untuk mengukur kemampuan berpikir kritis yaitu kemampuan menganalisis. Smith (2010) mengatakan bahwa inquiry merupakan kegiatan multifase yang melibatkan pengamatan, mengajukan pertanyaan, memeriksa buku atau sumber lain untuk mengevaluasi informasi yang telah diketahui dalam menyatakan fakta-fakta eksperimental, menggunakan alat untuk menganalisis dan menginterpretasi data serta mengusulkan jawaban.

Konstruktivisme merupakan tahap ketiga dari pembelajaran kontekstual. Peserta didik mengkonstruksi sendiri pengetahuan yang dimilikinya dengan cara membuat kesimpulan dan membandingkan jawaban sementara yang telah dibuat sebelumnya dengan hasil (kesimpulan) berdasarkan penemuan. Hasil pekerjaan peserta didik pada tahap ini digunakan untuk mengukur kemampuan berpikir kritis yaitu kemampuan menyimpulkan dan mengevaluasi. Kegiatan inquiry dan konstruktivisme dilakukan secara berkelompok (masyarakat belajar), sebagaimana menurut Eilks dan Kapanadze (2012) bahwa konstruktivisme tidak hanya berusaha untuk membuat peserta didik sebagai pemikir aktif, tapi untuk meningkatkan interaksi dan kolaborasi di antara peserta didik.

Pemodelan (modelling) merupakan bagian keempat dari pembelajaran kontekstual. Dalam pemodelan guru memperagakan sebuah percobaan tertentu, kemudian peserta didik memperhatikan demonstrasi guru dan menjelaskan (melakukan penalaran) terhadap fenomena yang terjadi saat demonstrasi. Hasil pekerjaan peserta didik pada tahap ini digunakan untuk mengukur kemampuan berpikir kritis peserta didik yaitu kemampuan eksplanasi. Menurut Facione (2011) kemampuan mengeksplanasi adalah 
kemampuan seseorang untuk menyajikan hasil penalaran dengan cara meyakinkan dan masuk akal.

Pada akhir pembelajaran, guru menyisakan waktu sejenak agar peserta didik melakukan refleksi berupa pernyataan langsung tentang hal-hal yang diperoleh saat pembelajaran serta kesan dan saran peserta didik mengenai pembelajaran yang telah dilaluinya (Hosnan, 2013 :272). Di akhir pembelajaran peserta didik melakukan kegiatan refleksi seperti mengungkapkan bagian materi yang telah dipahami dan bagian yang belum dipahami serta cara yang akan dilakukan oleh peserta didik untuk memahami materi tersebut. Peserta didik mengungkapkan bagain yang paling disukai dan tidak disukai dari peoses pembelajaran, serta memberikan saran dan masukan untuk perbaikan kegiatan belajar selanjutnya. Hasil pekerjaan peserta didik pada tahap ini digunakan untuk mengukur kemampuan berpikir kritis yaitu kemampuan regulasi diri berupa selfmonitor (memonitor proses kognisi diri) dan self-correct.

Draft awal modul IPA berbasis kontekstual yang telah disusun kemudian divalidasi oleh ahli materi, ahli pengembangan media dan ahli bahasa kemudian direvisi sesuai saran dan masukan sehingga menghasilkan draft II. Hasil penilaian oleh ahli materi, ahli media dan ahli bahasa mendapatkan nilai 3,74 dengan kategori sangat baik. Ahli materi melakukan validasi terhadap perangkat pembelajaran, materi ajar dan validasi soal berpikir kritis. Ahli pengembangan media melakukan validasi terhadap desain modul dan ahli bahasa melakukan validasi terhadap bahasa yang digunakan dalam modul. Draft II modul IPA berbasis kontekstual kemudian divalidasi oleh praktisi pendidikan dan teman sejawat sehingga menghasilkan draft III. Hasil penilaian oleh praktisi pendidikan dan teman sejawat memperoleh nilai 3,22, kategori kriteria baik dengan saran meliputi: a) tambahkan materi kalor tentang asas Black; b) tambahkan ikon berpikir kritis dalam modul; c) ikon untuk masingmasing komponen kontekstual harus terwakili; d) cover modul dapat didesain agar lebih bagus lagi; dan e) gambar cover modul kurang komunikatif. Secara keseluruhan berdasarkan hasil validasi dan revisi dari ahli, praktisi pendidikan dan teman sejawat maka modul IPA berbasis kontekstual telah memenuhi aspek kelayakan isi, kelayakan bahasa, kelayakan penyajian dan kesesuaian bahan ajar dengan pilar pendekatan kontekstual.

Uji coba tahap awal draf III modul IPA berbasis kontekstual dilakukan kepada 12 orang peserta didik kelas VII SMP Negeri 1 Weru secara paralel setelah melalui tahap validasi. Peserta didik dibagi menjadi tiga kelompok dengan ketentuan, kelompok 1 mengerjakan kegiatan belajar I, kelompok 2 mengerjakan kegiatan belajar II, dan kelompok 3 mengerjakan kegiatan belajar III. Data hasil analisis uji coba tahap awal yang diambil adalah data kemampuan berpikir kritis dan data hasil belajar peserta didik aspek pengetahuan. Data kemampuan berpikir kritis bertujuan untuk mengevaluasi kejelasan rumusan dan petunjuk soal kemampuan berpikir kritis. Hasil menunjukkan bahwa kemampuan berpikir kritis peserta didik paling rendah dengan kategori kurang pada kegiatan belajar II khususnya untuk soal analisis, inferensi dan evaluasi (gambar 1).

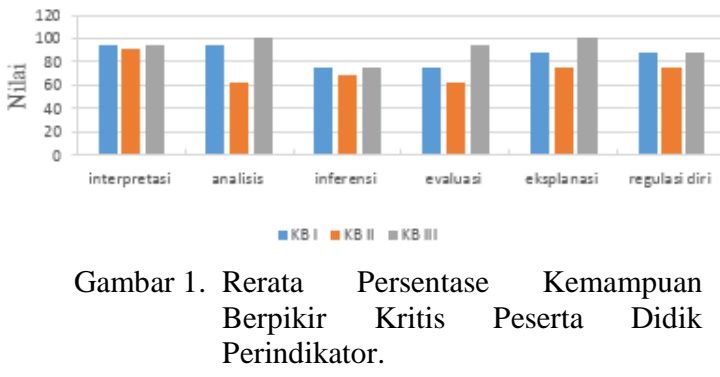

Data hasil belajar peserta didik aspek pengetahuan bertujuan untuk mengevaluasi kejelasan dan kelengkapan materi yang disajikan dalam modul serta kejelasan perumusan soal uji kompetensi. Peserta didik mengerjakan soal uji kompetensi pada akhir setiap kegiatan belajar setelah membaca uraian materi yang disajikan 
dalam modul. Rerata hasil menunjukkan bahwa, hasil pada kegiatan belajar II lebih rendah dibandingkan kegiatan belajar I dan III (gambar 2). Pada kegiatan belajar I peserta didik tidak dapat mengerjakan 2 soal yaitu soal nomor 2 dan nomor 9. Pada kegiatan belajar II ada 4 soal yang tidak dapat dikerjakan peserta didik yaitu soal nomor 2, 5, 8 dan 9. Peserta didik tidak dapat mengerjakan soal-soal tersebut karena berdasarkan analisis Quest yang telah dilakukan sebelumnya bahwa soal-soal tersebut berada pada kategori sukar. Selain itu, informasi penjelasan materi yang disampaikan dalam modul masih belum mewakili penjelasan tentang soal-soal tersebut. Pada kegiatan belajar III hanya soal nomor 9 yang tidak bisa dikerjakan peserta didik.

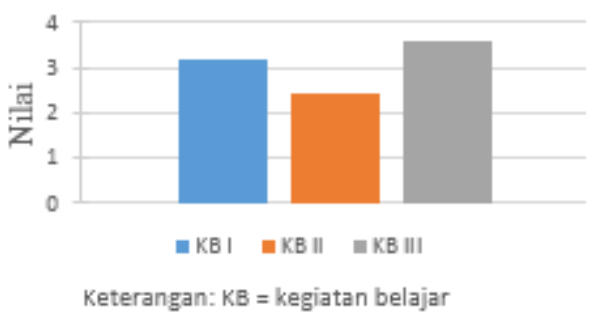

Gambar 2. Rerata Hasil Belajar Peserta Didik Aspek Pengetahuan Pada Uji Coba Produk.

Revisi modul IPA berbasis kontekstual setelah uji coba tahap awal meliputi: (1) penambahan petunjuk pengerjaan soal uji kemampuan berpikir kritis pada kegiatan belajar II terutama pada soal analisis dan inferensi; (2) revisi soal nomor 2 dan nomor 9 pada kegiatan belajar I, revisi dan penggantian soal nomor 2, 5, 8 dan 9 serta menambah penjelasan materi pada kegiatan belajar II, mengganti soal nomor 9 dengan bentuk yang berbeda dari sebelumnya Pada kegiatan belajar III. Berdasarkan hasil uji coba produk tahap awal dan revisi yang telah dilakukan maka modul IPA berbasis kontekstual dapat dilanjutkan untuk uji coba berikutnya sebagaimana pendapat Daryanto (2013: 2122) bahwa bila hasil uji coba modul layak, berarti modul tersebut siap diimplementasikan untuk kepentingan pembelajaran sesungguhnya. Sebaliknya, bila belum layak maka harus dilakukan perbaikan seperlunya. Setyowati dan Parmin (2013) juga mengatakan bahwa revisi yang dilakukan setelah uji coba skala kecil dinilai sangat berperan untuk meningkatkan persentase kelayakan modul.

Uji coba lapangan utama dilakukan pada 30 orang peserta didik. Hasil belajar dan hasil kemampuan berpikir kritis peserta didik dianalisis untuk dilakukan evaluasi terhadap keefektifan modul IPA berbasis kontekstual. Menurut Daryanto (2013: 32) bahwa modul yang dikembangkan jika memiliki tingkat keterbacaan yang tinggi serta sesuai dengan kemampuan peserta didik maka akan dapat membantu peserta didik mencapai tujuan pembelajaran secara efektif dan efisien.

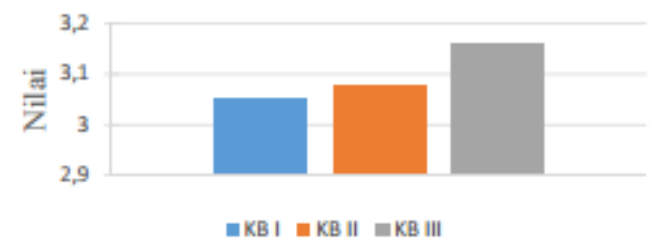

Gambar 3. Diagram Rerata Hasil Belajar Peserta Didik Aspek Pengetahuan.

Rerata hasil belajar aspek pengetahuan (pada gambar 3) yang diperoleh peserta didik setelah belajar dengan menggunakan modul IPA berbasis kontekstual pada kegiatan belajar (KB) I sebesar 3,05 dengan persentase ketuntasan $60 \%$, KB II sebesar 3,08 dengan persentase ketuntasan $70 \%$ dan KB III sebesar 3,16 dengan persentase ketuntasan $70 \%$, sebagaimana penelitian yang dilakukan oleh Hastuti (2014) bahwa, ketuntasan belajar klasikal pada penerapan modul IPA terpadu berbasis penemuan dengan tema spaghetti mencapai $75 \%$, artinya siswa yang mencapai tuntas belajar 21 siswa dan tidak tuntas 7 siswa. Hasil belajar peserta didik meningkat karena pembelajaran kontekstual membuat peserta didik berpartisipasi aktif dalam pembelajaran, berdiskusi dan melakukan penemuan serta berkesempatan untuk melakukan sendiri percobaan IPA 
sebagaimana menurut Rosana (2014) bahwa ciri keberhasilan belajar peserta didik $50 \%$ dari hal yang didengar dan dilihat, $70 \%$ dari hal yang dibicarakan dengan orang lain, $80 \%$ dari hal yang dialami sendiri dan $95 \%$ dari hal-hal yang diajarkan kepada orang lain.

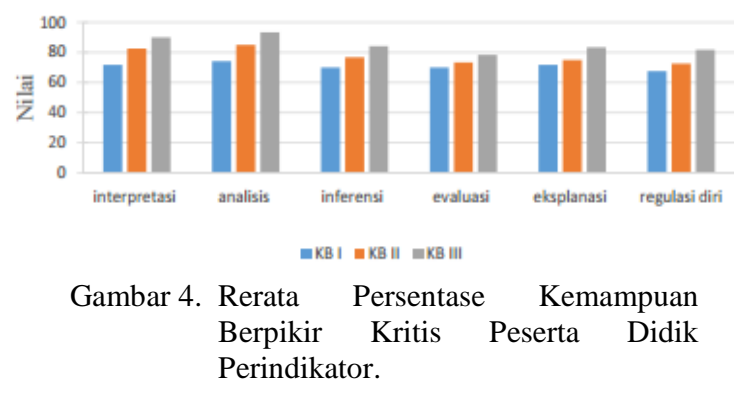

Rerata hasil kemampuan berpikir kritis peserta didik untuk masing-masing indikator pada kegiatan belajar (KB) I, II dan kegiatan belajar III (pada gambar 4) menunjukkan bahwa rerata persentase kemampuan interpretasi peserta didik meningkat pada KB I 71,67\%, KB II 82,5\% dan KB III 90\%. Kemampuan analisis peserta didik pada KB I 74,17\%, KB II 85\% dan KB III 93,3\%. Kemampuan inferensi pada KB I 70\%, KB II 76,7\% dan KB III $84,2 \%$. Kemampuan evaluasi pada KB I 70\%, KB II 73,3\% dan KB III 78,3\%. Kemampuan eksplanasi pada KB I 71,67\%, KB II 75\% dan KB III 83,3\%. Kemampuan regulasi diri pada KB I 67,5\%, KB II 72,5\% dan KB III $81,7 \%$. Hasil yang diperoleh sesuai dengan penelitian Valdez et al (2015) bahwa pembelajaran berbasis aktivitas dalam lingkungan pembelajaran kooperatif memotivasi peserta didik untuk berpikir kritis. Selain itu, pembelajaran berbasis aktivitas menarik, menyenangkan dan menggembirakan bagi peserta didik. Peningkatan kemampuan berpikir kritis peserta didik juga disebabkan implementasi pengintegrasian komponen kontekstual untuk meningkatkan kemampuan berpikir kritis saat proses pembelajaran berlangsung sebagaimana pendapat Berns dan Erickson (2001: 3) bahwa tujuan pembelajaran kontekstual dapat didasarkan pada penggunaan kemampuan berpikir tingkat tinggi seperti pemecahan masalah, berpikir kritis, dan pengambilan keputusan.

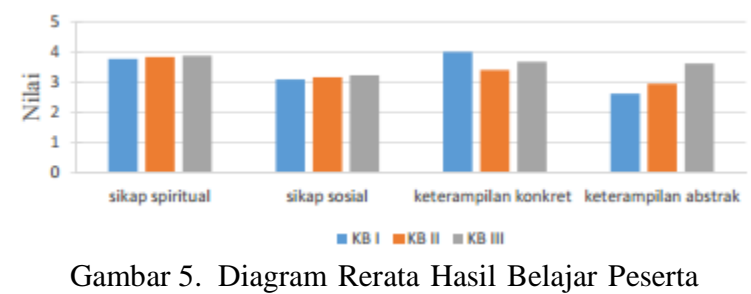
Didik Aspek Sikap dan Keterampilan.

Aspek sikap yang diukur adalah sikap spiritual dan sikap sosial sedangkan aspek keterampilan yang diukur adalah keterampilan konkret dan keterampilan abstrak. Data hasil belajar peserta didik (gambar 5) menunjukkan bahwa sikap spiritual peserta didik pada KB I sebesar 3,77, KB II sebesar 3,83 dan KB III sebesar 3,87. Sikap sosial peserta didik pada KB I sebesar 3,09, KB II 3,16, dan KB III 3,23, sedangkan hasil belajar aspek keterampilan yang diperoleh peserta didik setelah proses pembelajaran pada aspek keterampilan konkret untuk KB I sebesar 4,00, KB II mengalami penurunan menjadi 3,4 dan KB III mengalami peningkatan menjadi 3,67. Keterampilan abstrak pada KB I sebesar 2,62, KB II sebesar 2,95 dan KB III sebesar 3,62 .

Peningkatan kemampuan berpikir kritis dan hasil belajar peserta didik setelah penggunaan modul IPA berbasis kontekstual disebabkan karena proses pembelajaran menekankan pada penemuan dan pengkonstruksian konsep, sehingga peserta didik mengalami proses asimilasi dan akomodasi. Latihan-latihan yang diberikan kepada peserta didik secara berkelompok maupun secara mandiri masih berada dalam jangkauan kemampuan peserta didik (zona of proximal development) serta tugas-tugas yang dikerjakan peserta didik secara berkelompok juga menimbulkan interaksi kolaboratif antar peserta didik sehingga peserta didik secara langsung mengalami proses perancahan atau saling membantu untuk memecahkan masalah.

Respons peserta didik setelah pembelajaran menggunakan modul IPA 
berbasis kontekstual bahwa peserta didik merasa senang belajar dengan menggunakan modul IPA berbasis kontekstual karena modul mudah untuk dipelajari, tampilan modul menarik, modul dapat meningkatkan minat baca, dapat melatihkan kemampuan berpikir kritis di setiap kegiatan belajar serta gambar dan grafik dalam modul disajikan berwarna. Hal ini sesuai dengan penelitian Khuryati dan Kartika (2014) bahwa respons peserta didik terhadap modul pembelajaran IPA berbasis Contextual Teaching and Learning (CTL) untuk SMP/MTs kelas VII baik dalam uji coba lapangan skala kecil maupun uji coba lapangan skala besar dapat diterima oleh peserta didik sebagai salah satu sumber belajar. Respons guru terhadap modul IPA berbasis kontekstual dengan memberikan penilaian terhadap modul. Rerata nilai yang diperoleh sebesar 3,55 dengan kriteria sangat baik dan menurut guru IPA bahwa modul dapat diimplementasikan. Hal ini sesuai dengan penelitian yang dilakukan oleh Izzati, Hindarto dan Pamelasari (2013) bahwa Penilaian angket tanggapan guru mendapatkan tanggapan yang sangat baik dan respon peserta didik terhadap modul untuk setiap item penilaian berkisar antara baik dan sangat baik.

Revisi modul IPA berbasis kontekstual setelah Uji coba lapangan utama yaitu pada kesalahan penulisan kata. Satu orang peserta didik memberikan saran untuk menambah durasi waktu pembelajaran. Penambahan durasi waktu pembelajaran dilakukan apabila waktu yang disediakan tidak cukup untuk menyelasaikan satu kegiatan belajar, namun pada obsevasi selama kegiatan pembelajaran waktu yang disediakan cukup yaitu 2 jam sehingga tidak perlu dilakukan penambahan.

\section{Kesimpulan dan Rekomendasi}

Berdasarkan tujuan penelitian, hasil dan pembahasan maka dapat disimpulkan bahwa: (1) modul IPA berbasis kontekstual memiliki karakteristik yaitu langkah pembelajaran pada modul memuat langkah pembelajaran berbasis kontekstual yang mengintegrasikan kemampuan berpikir kritis pada setiap tahapnya, masing-masing kegiatan belajar terdiri atas satu kompetensi dasar dan modul IPA berbasis kontekstual bersifat self Instruction; (2) modul IPA berbasis kontekstual termasuk kategori layak karena telah melalui uji kelayakan dari ahli materi, ahli media dan ahli bahasa dengan nilai 3,74 kategori sangat baik, praktisi pendidikan dan teman sejawat dengan nilai 3,22 kategori baik, serta melalui tahap uji coba produk dan revisi; (3) modul IPA berbasis kontekstual efektif meningkatkan kemampuan berpikir kritis dan prestasi belajar aspek pengetahuan, keterampilan dan sikap peserta didik serta respons peserta didik dan guru IPA saat uji coba lapangan utama bahwa modul IPA berbasis kontekstual dapat digunakan dalam pembelajaran IPA sebagai bahan ajar.

Berdasarkan hasil dan pembahasan maka rekomendasi dalam penelitian ini adalah perlu dilakukan penelitian lanjutan uji coba lapangan operasional, revisi produk akhir dan tahap diseminasi-implementasi produk modul IPA berbasis kontekstual untuk kontrol kualitas.

\section{Daftar Pustaka}

Berns, R. G., \& Patricia M. Erickson. (2001). Contextual Teaching and Learning: Preparing Students for the New Economy. The Highlight Zone: Research (C) Work No. 5. National Dissemination Center for Career and Technical Education, Columbus, $\mathrm{OH}$. Washington, DC. http://www.nccte.com/publications/infosinthesys.

Daryanto. (2013). Menyusun Modul: Bahan Ajar untuk Persiapan Guru dalam Mengajar. Yogyakarta: Gava Media.

Facione, P. A. (2011). Critical Thinking: What It Is and Why It Counts. Measured Reasons and The California Academic Press, Millbrae, CA. Journal. ISBN 13: 978-1-891557-07-1. 
Hastuti, E. T., dkk. (2014). Pengembangan Modul IPA Terpadu Berbasis Penemuan Dengan Tema Spaghetti. Prosiding Seminar Nasional Fisika dan Pendidikan Fisika. Volume 5 Nomor 1 2014 ISSN : 2302-7827.

Hosnan, M. (2014). Pendekatan Saintifik dan Kontekstual dalam Pembelajaran Abad 21. Bogor: Ghalia Indonesia.

Izzati, N., Hindarto, N., \& S. D. Pamelasari. (2013). Pengembangan Modul Tematik dan Inovatif Berkarakter Pada Tema Pencemaran Lingkungan untuk Siswa Kelas VII SMP. Jurnal Pendidikan IPA Indonesia 2 (2) (2013) 183-188.

Khuryati., \& Kartika, I. (2014). Pengembangan Modul Pembelajaran IPA Terpadu Berbasis Contextual Teaching and Learning (CTL) untuk SMP/MTs Kelas VII. Jurnal Vol. X No. 1, April 2014/1435: 50-58. ISSN 1829-5266 (print) ISSN 2301-8550.

Lambertus. (2009). Pentingnya Melatih Keterampilan Berpikir Kritis dalam Pembelajaran Matematika di SD. Forum Kependidikan, Volume 28, Nomor 2, Maret 2009.

Prastowo, A. (2014). Pengembangan Bahan Ajar Tematik: Tinjauan Teoritis dan Praktik. Jakarta: Kencana.

Rosana, D. (2014). Evaluasi Pembelajaran Sains: Asesmen Pendekatan Saintifik Pembelajaran Terpadu. Yogyakarta: UNY.

Setyowati, R., Parmin, \& Widiyatmoko, A. (2013). Pengembangan Modul IPA Berkarakter Peduli Lingkungan Tema Polusi Sebagai Bahan Ajar Siswa SMK N 11 Semarang. Unnes Science Education Journal 2 (2) (2013).

Smith, B. P. (2010). Instructional Strategies in Family and Consumer Sciences: Implementing the Contextual Teaching and Learning Pedagogical Model. Journal of Family \& Consumer Sciences Education, 28(1).

Sugiyono. (2011). Metode Penelitian Kuantitatif, Kualitatif dan $R \& D$. Bandung: Alfabeta.
Thelma M. G. et al. (2007). Critical Thinking In Science. http://www.ucalgary.ca/ihpst07/proceedings/IHPST07\%20papers/117 \%20Gunn.pdf. Diakses 06/05/2015.

Valdez, A. V. et al. (2015). Developing Critical Thinking through Activity -Based and Cooperative Learning Approach in Teaching High School Chemistry. International Journal of Social Science and Humanity, Vol. 5, No. 1, January 2015.

Winkel. W. S. (2009). Psikologi Pengajaran. Yogyakarta: Media Abadi 